\title{
Temporal dynamics of ikaite in experimental sea ice
}

\author{
S. Rysgaard ${ }^{1,2,3,4}$, F. Wang ${ }^{1,5}$, R. J. Galley ${ }^{1}$, R. Grimm ${ }^{6}$, D. Notz $^{6}$, M. Lemes ${ }^{1}$, N.-X. Geilfus ${ }^{1,4}$, A. Chaulk ${ }^{1}$, \\ A. A. Hare ${ }^{1}$, O. Crabeck $^{1}$, B. G. T. Else ${ }^{1}$, K. Campbell ${ }^{1}$, L. L. Sørensen ${ }^{4}$, J. Sievers ${ }^{4,7}$, and T. Papakyriakou ${ }^{1}$ \\ ${ }^{1}$ Centre for Earth Observation Science, Department of Environment and Geography, University of Manitoba, Winnipeg, MB \\ R3T 2N2, Canada \\ ${ }^{2}$ Department of Geological Sciences, University of Manitoba, Winnipeg, MB R3T 2N2, Canada \\ ${ }^{3}$ Greenland Climate Research Centre, Greenland Institute of Natural Resources, 3900 Nuuk, Greenland \\ ${ }^{4}$ Arctic Research Centre, Aarhus University, 8000 Aarhus, Denmark \\ ${ }^{5}$ Department of Chemistry, University of Manitoba, Winnipeg, MB R3T 2N2. Canada \\ ${ }^{6}$ Max Planck Institute for Meteorology, Hamburg, Germany \\ ${ }^{7}$ Aarhus University, Department of Environmental Science, 4000 Roskilde, Denmark
}

Correspondence to: S. Rysgaard (soeren.rysgaard@ad.umanitoba.ca)

Received: 7 October 2013 - Published in The Cryosphere Discuss.: 19 December 2013

Revised: 10 June 2014 - Accepted: 12 June 2014 - Published: 8 August 2014

\begin{abstract}
Ikaite $\left(\mathrm{CaCO}_{3} \cdot 6 \mathrm{H}_{2} \mathrm{O}\right)$ is a metastable phase of calcium carbonate that normally forms in a cold environment and/or under high pressure. Recently, ikaite crystals have been found in sea ice, and it has been suggested that their precipitation may play an important role in air-sea $\mathrm{CO}_{2}$ exchange in ice-covered seas. Little is known, however, of the spatial and temporal dynamics of ikaite in sea ice. Here we present evidence for highly dynamic ikaite precipitation and dissolution in sea ice grown at an outdoor pool of the Sea-ice Environmental Research Facility (SERF) in Manitoba, Canada. During the experiment, ikaite precipitated in sea ice when temperatures were below $-4{ }^{\circ} \mathrm{C}$, creating three distinct zones of ikaite concentrations: (1) a millimeter-to-centimeter-thin surface layer containing frost flowers and brine skim with bulk ikaite concentrations of $>2000 \mu \mathrm{mol} \mathrm{kg}{ }^{-1}$, (2) an internal layer with ikaite concentrations of $200-400 \mu \mathrm{mol} \mathrm{kg}{ }^{-1}$, and (3) a bottom layer with ikaite concentrations of $<100 \mu \mathrm{mol} \mathrm{kg}{ }^{-1}$. Snowfall events caused the sea ice to warm and ikaite crystals to dissolve. Manual removal of the snow cover allowed the sea ice to cool and brine salinities to increase, resulting in rapid ikaite precipitation. The observed ikaite concentrations were on the same order of magnitude as modeled by FREZCHEM, which further supports the notion that ikaite concentration in sea ice increases with decreasing temperature. Thus, varying snow conditions may play a key role in ikaite precipitation and dissolution in sea ice. This could have a major implication for
\end{abstract}

$\mathrm{CO}_{2}$ exchange with the atmosphere and ocean that has not been accounted for previously.

\section{Introduction}

Throughout the last decade, sea ice extent has decreased rapidly in the Arctic Ocean (e.g., Cavalieri and Parkinson, 2012). This ocean represents an important sink for $\mathrm{CO}_{2}$, with current estimates of net air-to-sea $\mathrm{CO}_{2}$ fluxes at 66 to 199 $\mathrm{Tg} \mathrm{C} \mathrm{yr}^{-1}$ (Bates and Mathis, 2009; Parmentier et al., 2013). To understand how the oceanic $\mathrm{CO}_{2}$ sink will change with a reduced sea ice cover, it is important to understand the driving factors behind the air-sea exchange of $\mathrm{CO}_{2}$. The precipitation of the metastable mineral ikaite $\left(\mathrm{CaCO}_{3} \cdot 6 \mathrm{H}_{2} \mathrm{O}\right)$ in polar sea ice may be critical in modifying the quantity of dissolved $\mathrm{CO}_{2}$ in the surface ocean $\left(p \mathrm{CO}_{2}\right)$, with potentially important impacts on the global carbon cycle (Rysgaard et al., 2011).

Ikaite crystals have been reported in sea ice from both hemispheres (Dieckmann et al., 2008, 2010). However, the spatial and temporal dynamics of ikaite within sea ice are poorly known. Recent studies using microscopic imaging of sea ice thin sections to examine ikaite in situ have revealed ikaite crystals to concentrate in the interstices between the ice platelets in both granular and columnar sea ice (Rysgaard et al., 2013). Their concentration appears to decrease from 
the ice surface towards the ice-water interface. Ikaite crystals are formed during winter conditions (Rysgaard et al., 2013; Geilfus et al., 2013a), but at present it is not known if they grow continuously during cold conditions or if they form and dissolve in response to variations in environmental conditions such as snow cover. Nonetheless, during summer it has been shown that dissolving ikaite crystals from melting sea ice adds considerable amounts of total alkalinity (TA) to the surface waters, thereby reducing surface water $p \mathrm{CO}_{2}$ and increasing the potential for seawater uptake of $\mathrm{CO}_{2}$ from the atmosphere (Rysgaard et al., 2012). Ikaite could have a major impact on air-sea $\mathrm{CO}_{2}$ exchange rates if the crystals continually precipitate and dissolve in the winter. Thus, a better understanding of the dynamic ikaite production and dissolution is needed.

Here, we present observations of ikaite conditions in newly formed sea ice, thin sea ice under different snow conditions, and in melting sea ice. In addition, we employed the FREZCHEM model (Marion et al., 2010) to calculate theoretical equilibrium ikaite concentrations as a function of different sea ice temperatures in Sea-ice Environmental Research Facility (SERF) seawater with different $p \mathrm{CO}_{2}$ values. Finally, we discuss our findings in relation to $\mathrm{CO}_{2}$ system dynamics in sea-ice-covered seas.

\section{Methods}

\subsection{Ice tank description, sampling, and analysis}

An experiment was performed at SERF at the University of Manitoba, Winnipeg, Canada, in an outdoor pool measuring $18.3 \mathrm{~m}$ by $9.1 \mathrm{~m}$ in surface area and $2.6 \mathrm{~m}$ in depth, with an approximate operating volume of $380 \mathrm{~m}^{3}$. The pool was exposed to natural ambient temperatures, winds, and solar radiation, and contained artificial seawater (ASW). The ASW was formulated by dissolving large quantities of various rock salts into local groundwater to mimic the major ion composition of natural seawater $(S=32.9)$. Most ions were within $15 \%$ deviation from the natural composition (Millero, 2006), with the exception that the concentrations of $\mathrm{Mg}^{2+}$ and $\mathrm{SO}_{4}^{2-}$ were 49.1 and $26.5 \%$ lower, respectively (Table 1). Sea ice was grown in the pool from open water on 13 January (2013) and reached $20 \mathrm{~cm}$ in thickness on 26 January, after which the sea ice was melted by circulating heated ethylene glycol through a closed-loop hose fixed at the bottom of the pool.

Three events of snowfall occurred during the experiment. The first event occurred from 14 to 15 January, covering the sea ice surface with $1 \mathrm{~cm}$ of snow. The second event deposited 6-9 $\mathrm{cm}$ snow over the entire pool from 18 to 23 January. Then, on the morning of 23 January, the snow was manually cleared to investigate the insulating effect of snow on ice temperature and ikaite formation. This was followed by a final snowfall event, which began around noon on 24 Jan-
Table 1. Seawater composition used at SERF and in the FREZCHEM modeling.

\begin{tabular}{lrrr}
\hline Composition & $\begin{array}{r}\text { SERF seawater } \\
(\text { Ex 2.2) }\end{array}$ & $\begin{array}{r}\text { Natural seawater } \\
(S=32.9)^{*}\end{array}$ & $\begin{array}{r}\text { Difference } \\
(\%)\end{array}$ \\
\hline $\mathrm{Na}^{+}\left(\mathrm{mol} \mathrm{kg}^{-1} \mathrm{H}_{2} \mathrm{O}\right)$ & 0.4719 & 0.4569 & 3.3 \\
$\mathrm{~K}^{+}\left(\mathrm{mol} \mathrm{kg}^{-1} \mathrm{H}_{2} \mathrm{O}\right)$ & 0.009796 & 0.009945 & -1.5 \\
$\mathrm{Ca}^{2+}\left(\mathrm{mol} \mathrm{kg}^{-1} \mathrm{H}_{2} \mathrm{O}\right)$ & 0.011478 & 0.010020 & 14.5 \\
$\mathrm{Mg}^{2+}\left(\mathrm{mol} \mathrm{kg}^{-1} \mathrm{H}_{2} \mathrm{O}\right)$ & 0.026167 & 0.051456 & -49.1 \\
$\mathrm{Cl}^{-}\left(\mathrm{mol} \mathrm{kg}^{-1} \mathrm{H}_{2} \mathrm{O}\right)$ & 0.5134 & 0.5318 & -3.5 \\
$\mathrm{Br}^{-}\left(\mathrm{mol} \mathrm{kg}^{-1} \mathrm{H}_{2} \mathrm{O}\right)$ & 0.00092 & 0.00082 & 12.9 \\
$\mathrm{SO}_{4}^{2-}\left(\mathrm{mol} \mathrm{kg}^{-1} \mathrm{H}_{2} \mathrm{O}\right)$ & 0.02021 & 0.02750 & -26.5 \\
& & & \\
$\mathrm{pH}$ & 8.2 & & \\
$\mathrm{TA}(\mu \mathrm{mol} \mathrm{kg}$ & & & \\
$S$ & 2380 & & \\
* Extrapolated from the $S=35$ standard seawater (Millero, 2006) to $S=32.9$. &
\end{tabular}

uary and deposited $8 \mathrm{~cm}$ of snow by 27 January, covering the entire pool until the end of the experiment on 30 January.

Ambient temperature $(T)$ of seawater and bulk ice were recorded by automated type- $T$ thermocouple arrays fixed into the outdoor pool, and $2 \mathrm{~m}$ air temperature and relative humidity were measured using a Vaisala HMP45C probe at a meteorological station located at the SERF site. Solar irradiance was continuously recorded by an Eppley Precision Spectral Pyranometer (range: $0.285-2.8 \mu \mathrm{m}$ ) mounted $\sim 10 \mathrm{~m}$ above the sea ice surface. In addition, estimated photosynthetically active radiation (PAR) values at the ice bottom were recorded with Alec MkV/L PAR sensors throughout the study and ranged from 0 to $892 \mu \mathrm{mol}$ photons $\mathrm{m}^{-2} \mathrm{~s}^{-1}$. Sea ice cores were extracted with a MARK II coring system (Kovacs Enterprises) and cut into 1 to $2 \mathrm{~cm}$ sections for bulk salinity analyses. Salinity $(S)$ was determined from sample conductivity and temperature as per Grasshoff et al. (1983).

For analysis of ikaite, frost flowers (FFs) and brine skim (BS) samples were collected with a precleaned ceramicbladed knife and transported cold in clean plastic bags to a cold laboratory $\left(-20^{\circ} \mathrm{C}\right)$ within $20 \mathrm{~min}$ and analyzed within $1-2 \mathrm{~h}$. In addition, sea ice cores were extracted with a MARK II coring system and kept cold during the $20 \mathrm{~min}$ transport to a cold laboratory and also processed within $1-2 \mathrm{~h}$. Ice cores were collected from a bridge and it was not necessary to walk on the sea ice. Cores were collected from one end of the pool (half a meter away from the edge of the pool) during the campaign period. Cores were collected at least $20 \mathrm{~cm}$ away from previously cored sites. The bridge could be moved, ensuring only undisturbed sea ice cores were collected. In the cold lab, sea ice cores were cut into $1-2 \mathrm{~cm}$ sections by a precleaned stainless steel band saw. To document the abundance and concentrations of ikaite crystals in sea ice, $20-150 \mathrm{mg}$ of sea ice were cut off using a ceramic-bladed knife at three random places within each sea ice section. An equal weight of BS was scraped from the ice surface layer of each core using a similar knife, and FFs were carefully collected using two knives. The sea ice, BS, and FFs were weighed and 
placed onto a glass slide that rested on a chilled aluminum block with a $1 \mathrm{~cm}$ central viewing hole, then brought into a warm laboratory $\left(20^{\circ} \mathrm{C}\right)$. There they were inspected under a microscope (Leica DM IL LED equipped with a Leica DFC 295 camera and Leica Application Suite v. 4.0.0. software) under 100-400 magnification as they were allowed to melt. A few seconds after the sea ice had melted the first image was taken. This image was used to document the amount and concentration of ikaite crystals (further details given below). After 2-5 min the second image was taken and compared with the first one (For further details, see Rysgaard et al., 2013). If crystals dissolved, they were assumed to be ikaite. Three photos, each covering $1.07 \mathrm{~mm}^{2}$ of the counting area, were imaged in this fashion. The area of the melted sea ice sample was determined after thawing to calculate the counted area to total area ratio. Ikaite crystals and other precipitates were observed to settle to the glass slide rapidly after ice crystal melt due to their high density. In total, three replicate sea ice sub-samples were processed from each sea ice section, resulting in nine replicate images for each 1 to $2 \mathrm{~cm}$ vertical sea ice section, as well as for each FF and BS sample. Ikaite could be distinguished from mirabilite and gypsum. Mirabilite crystals dissolve before temperatures increase to $0^{\circ} \mathrm{C}$ and are therefore not included in our quantification of ikaite. In addition, ikaite crystals in sea ice can also be distinguished morphologically from gypsum and mirabilite (Geilfus et al., 2013b; unpublished data, Marcos Lemes, University of Manitoba). Furthermore, bubbles are easily distinguished as they appear as large circles with a darker color inside - and we also avoided these in the image analysis. All crystal forms have been identified by X-ray techniques (see below). The elemental composition of the ikaite crystals was also qualitatively analyzed by inductively coupled plasma-mass spectrometry (ICP-MS), which confirmed the presence of high levels of calcium. Quantitative data were not obtained, as isolating ikaite crystals from sea ice is not straightforward because they dissolve rather rapidly.

The abundance and concentration of the crystals that dissolved and were hence identified as ikaite were calculated from the images using the software ImageJ $(1.45 \mathrm{~s})$. Individual images were brightness-, contrast-, and color-adjusted prior to image analysis (see Rysgaard et al., 2013, for details) to convert to a binary image with crystals depicted as black on a white background. From this binary image, the area of ikaite crystals was calculated and converted to a volume using the relative dimensions of ikaite crystals (Rysgaard et al., 2012; see also Sect. 3). The microscope slides contained counting cells. The amount of crystals was documented within one-three counting cells and then multiplied with the number of cells that was covered by melt water after sea ice had melted. The mass and number of moles of ikaite crystals could then be determined from crystal density $\left(1.78 \mathrm{~g} \mathrm{~cm}^{-3}\right)$ and molar weight $\left(208.18 \mathrm{~g} \mathrm{~mol}^{-1}\right)$, which in turn permitted conversion to concentration (in $\mu \mathrm{mol} \mathrm{kg}{ }^{-1}$ melted sea ice) after carefully weighing the sample on a high-precision digi- tal scale. Brine concentrations of ikaite were calculated from measured bulk ikaite concentrations divided by the brine volume. Brine volume was estimated from measurements of bulk salinity, temperature, and density according to Cox and Weeks (1983). The standard error of the measured ikaite concentration varied both temporally and spatially. Across all dates and sea ice sections the average standard error of the mean was $35 \%$ of the mean value, with a range of 7 to $60 \%$. As an example, the sea ice ikaite concentrations in the central part of sea ice on 23 January was $200 \pm 70 \mu \mathrm{mol} \mathrm{kg}^{-1}$.

Sea ice subsamples were also brought to an X-ray laboratory (Department of Geological Sciences at the University of Manitoba, Canada) within $20 \mathrm{~min}$. There, $20-90 \mathrm{mg}$ subsamples of sea ice were mounted onto a cold glass slide resting on a chilled aluminum block containing a $1 \mathrm{~cm}$ central viewing hole. Crystals were first examined with a polarized light microscope to assess their optical properties and then mounted for X-ray study using a stereo binocular microscope. Crystals were dragged across the cold glass slide using a metal probe and immersed into a drop of special purpose sampling oil that restricted sublimation. Each crystal was then scooped up with a low X-ray scattering microloop and instantly transferred to the nitrogen cold stream $\left(-10^{\circ} \mathrm{C}\right)$ on the X-ray diffraction instrument with a magnetic coupling goniometer head. The X-ray diffraction instrument consisted of a Bruker D8 three-circle diffractometer equipped with a rotating anode generator (MoK $\alpha \mathrm{X}$-radiation), multilayer optics, APEX II CCD detector, and an Oxford 700 Series liquid$\mathrm{N}$ Cryostream. The intensities of more than 100 reflections were harvested from six frame series (each spanning $15^{\circ}$ in either $\omega$ or $\varphi$ ) collected to $60^{\circ} 2 \theta$ using 0.6 s per $1^{\circ}$ frame with a crystal-to-detector distance of $5 \mathrm{~cm}$.

\subsection{FREZCHEM modeling}

Ikaite precipitation in sea ice was modeled by FREZCHEM (version 13.3), an equilibrium chemical thermodynamic model parameterized for concentrated solutions (up to $20 \mathrm{~mol} \mathrm{~kg}^{-1}\left(\mathrm{H}_{2} \mathrm{O}\right)$ ) and subzero temperatures (down to $-70^{\circ} \mathrm{C}$ ) (Marion and Kargel, 2008; Marion et al., 2010). The model uses the Pitzer approach to correct for activity coefficients of solutes in concentrated solutions. The FREZCHEM mineral database includes a variety of stable and metastable carbonate minerals of $\mathrm{Ca}$ (e.g., calcite, dolomite, aragonite, vaterite) (Marion, 2001). The solubility product of ikaite was based on the experimental data of Bischoff et al. (1993) extrapolated to low temperatures by Marion (2001). All other thermodynamic constants used were the default values provided by the model (Marion, 2001). The model inputs included the concentrations of all the major ions and the values of salinity (32.9) and TA ( $\left.2380 \mu \mathrm{mol} \mathrm{kg}{ }^{-1}\right)$ of the SERF seawater as shown in Table 1 . Our calculation was done by following the seawater freezing from 0 to $-16^{\circ} \mathrm{C}$ at a step value of $0.5^{\circ} \mathrm{C}$. Three computations were made where the freezing process of the system were open to $p \mathrm{CO}_{2}=390,1000$ and 
$5000 \mu a t m$, respectively. The model was run under "equilibrium crystallization"; that is, solid phases precipitated at any given temperature were allowed to dissolve and reprecipitate when temperature changed.

The FREZCHEM model simulates the formation of ice, along with other possible minerals, as seawater freezes in a system that is "closed" with respect to matter (e.g., no loss of salt to the underlying water column) except for gaseous components (in this case $\mathrm{CO}_{2}$ ), which are allowed to transfer into or out of the system (Marion and Kargel, 2008). It considers both changes in concentrations due to brine volume changes, and dependence of activity and thermodynamic constants on temperature. The modeling is based on the assumption that chemical species in the sea ice environment (ice, brine, and air) have reached thermodynamic equilibrium, and most of the thermodynamic constants used in the model were extrapolated to low temperatures rather than being determined experimentally. Nevertheless, the model has shown promising applications in exploring cold geochemical processes associated with seawater freezing (Marion et al., 1999, 2010), including the production of ikaite (Rysgaard et al., 2013).

\section{Results}

Figure 1 shows examples from 22 January at 9 a.m. central time zone (UTC - 06:00) of ikaite crystals in BS, at $2-3 \mathrm{~cm}$ depth, and at $9-10 \mathrm{~cm}$ depth within the sea ice. Ikaite crystals become easily visible on the microscope in the laboratory when the sea ice melts. Figure 1a shows an image example from BS consisting of 159 crystals observed a few seconds after a $102 \mathrm{mg}$ BS sample was melted. Figure $1 \mathrm{~b}$ presents a software processing image of Fig. 1a used to calculate the number and area of crystals, in this case $2.1 \%$ of the counting area, corresponding to an ikaite concentration of $4590 \mu \mathrm{mol} \mathrm{kg}^{-1}$ bulk ice (unless otherwise specified, all the concentrations are bulk ice concentrations). Ikaite crystals at $2-3 \mathrm{~cm}$ depth (Fig. 1c, d) covered $0.4 \%$ of the counting area, corresponding to $950 \mu \mathrm{mol} \mathrm{kg}-1$; ikaite crystals at $9-10 \mathrm{~cm}$ depth (Fig. 1e, f) covered $0.05 \%$ of the counting area, corresponding to $90 \mu \mathrm{mol} \mathrm{kg}{ }^{-1}$. The crystals (a few $\mu \mathrm{m}$ to $100 \mu \mathrm{m}$ in size) observed in the sea ice were highly transparent with a rhombic morphology and showed uniform extinction under cross-polarized light, suggesting that they were simple single crystals. All X-ray reflections fitted well to a monoclinic C-centered cell with $\mathrm{a}(\AA)=8.816(14)$, $\mathrm{b}(\AA)=8.317(9), \mathrm{c}(\AA)=11.042(2), \beta\left(^{\circ}\right)=110.612(9)$, and $\mathrm{V}\left(\AA^{3}\right)=757.8(3)$. From the general shape, optical properties, and unit-cell determination, the crystals examined were confirmed to be ikaite (after Hesse and Küppers, 1983). Crystal shape varied (Fig. 1). To keep it as simple as possible we approximated ikaite volume as determined by the $a, b$, and $\mathrm{c}$ components given above $(1 \times 1.06 \times 1.32)$ assuming that crystals settled on the side with the largest area. A unit cell with $\mathrm{a}, \mathrm{b}, \mathrm{c}$, and $\beta$ as given above and additional an- gles of $\alpha=90^{\circ}$ and $\gamma=90^{\circ}$ has a volume of 757.8 cubic ångstroms. A rectangular prism with the same dimensions but with $\beta=90^{\circ}$ instead of $110.612^{\circ}$ has a volume of 809.6 cubic ångstroms. So our approximate rectangular box could slightly overestimate the volume by about $7 \%$.

Observations of atmospheric conditions, sea ice thickness, sea ice and water temperatures, salinity, and ikaite concentration are shown for the duration of the experiment in Fig. 2. Near the start of the experiment (13 January), air temperatures ranged from -15 to $-25^{\circ} \mathrm{C}$ (Fig. 2a), allowing rapid initial ice growth that reached a thickness of $\sim 5 \mathrm{~cm}$ by the evening of 14 January (Fig. 2b). At that point the first ikaite crystals were observed in FFs and BS (Fig. 2d), with concentrations in excess of $1000 \mu \mathrm{mol} \mathrm{kg}{ }^{-1}$ (Fig. 2d). No ikaite crystals were observed in the ice column itself, which remained relatively warm $\left(\sim-2\right.$ to $-4{ }^{\circ} \mathrm{C}$, Fig. $\left.1 \mathrm{~b}\right)$.

Initial sea ice growth in SERF occurred with ice attachment to the sides of the pool, resulting in the development of a hydrostatic pressure head that caused flooding of the sea ice surface between 15 and 18 January, and an increase in surface bulk ice salinity (Fig. 2c). Subsequently, cuts were made with a large saw around the perimeter of the pool to allow the ice to float, and a pressure release valve was installed to prevent further flooding. Over the same time period, a snow deposition event occurred, and ice temperatures in the top $5 \mathrm{~cm}$ oscillated between relatively warm periods $\left(\sim-3^{\circ} \mathrm{C}\right)$ and relatively cold periods $\left(\sim-7^{\circ} \mathrm{C}\right.$, Fig. 1b). During a cold period on 14-15 January the first ikaite crystals in bulk ice were observed near the surface (Fig. 2d). A subsequent warming early on 16 January appeared to dissolve the crystals, which then reformed later in the day when ice temperatures dropped once again. Ikaite was also observed on 18 January near the bottom of the ice in a warmer, but more saline, layer of the ice.

One square meter of the surface was cleared from snow in the evening of 21 January to test how ikaite formation was affected. Ikaite was observed to form in high numbers on the surface ice in the morning of 22 January (data included in Fig. 2d). Thus, the surface of the entire sea ice was cleared of snow the morning of 23 January by shoveling. Air temperature during this time, and for the next 2 days, was cold at approximately $-22{ }^{\circ} \mathrm{C}$ or lower. Shortly after the snow was removed, temperatures dropped significantly throughout the entire sea ice column, which had reached a thickness of over $20 \mathrm{~cm}$ at that time (Fig. 2b). Bulk salinities increased because of surface flooding, and high ikaite concentrations were observed in FFs, BS, and the sea ice. Ikaite crystals in the ice were formed within several hours after snow clearing, indicating dynamic conditions of ikaite formation on short timescales.

Shortly after the snow-clearing experiment, a third snowfall event began at midnight on 24 January, covering the entire pool with $4-8 \mathrm{~cm}$ of dry snow by 26 January. This resulted in an increase in sea ice temperature and reduced brine salinity. However, ikaite crystals concentrations remained 


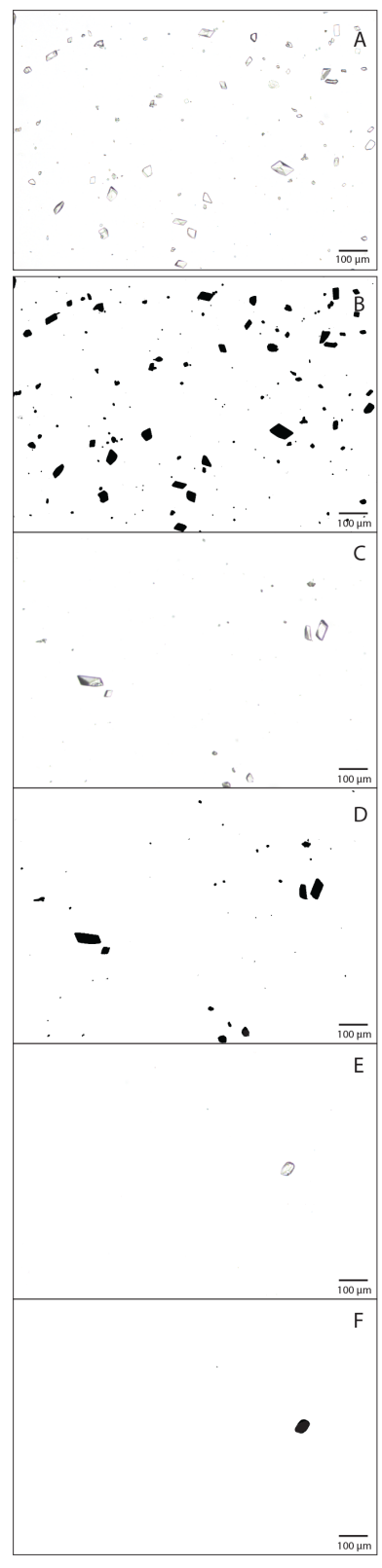

Figure 1. (A) Microscopic images of ikaite crystals a few seconds after melting $102 \mathrm{mg}$ sea ice (brine skim sample) from 22 January. Image represents a very small fraction $(3 \mu \mathrm{g})$ of the sample. (B) Software (ImageJ 1.45 s) processing of image (A) to find the number (159) and area (2.1\% of counting area) of the crystals. (C) Microscopic images of ikaite crystals a few seconds after melting 86 $\mathrm{mg}$ sea ice (from $2 \mathrm{~cm}$ depth) from 22 January. Image represents a very small fraction $(3 \mu \mathrm{g})$ of the sample. (D) Software processing of image (C) to find the number (31) and area ( $0.4 \%$ of counting area) of the crystals. (E) Microscopic images of ikaite crystals a few seconds after melting $42 \mathrm{mg}$ sea ice (from $10 \mathrm{~cm}$ depth) from $22 \mathrm{Jan}$ uary. Image represents a very small fraction $(3 \mu \mathrm{g})$ of the sample. (F) Software processing of image (E) to find the number (1) and area $(0.05 \%$ of counting area) of the crystals. high in the top $10 \mathrm{~cm}$ of the sea ice. After ice melt was initiated by turning on the heater on 26 January, sea ice temperatures rapidly increased and sea ice thickness rapidly decreased. This caused brine salinities to decrease and ikaite crystals in the sea ice to dissolve. The experiment was terminated on 30 January when sea ice had nearly disappeared.

\section{Discussion}

The ikaite concentrations in the present study are the highest reported from sea ice, with ikaite concentrations in brine skim and frost flowers of $>2000 \mu \mathrm{mol} \mathrm{kg}{ }^{-1}$. These concentrations are several times higher than ikaite concentrations in FFs and BS reported from Barrow, Alaska ( $\max 25 \mu \mathrm{mol} \mathrm{kg}^{-1}$; Geilfus et al., 2013a), but similar to FF and BS ikaite concentrations found in NE Greenland (500$3000 \mu \mathrm{mol} \mathrm{kg}{ }^{-1}$; Barber et al., 2014). In this SERF study, frost flowers formed at air temperatures ranging from -15 to $-30{ }^{\circ} \mathrm{C}$ and a relative humidity of $70-80 \%$. It is still not fully understood whether FFs form due to deposition of atmospheric water vapor to the sea ice surface, or from sublimation of the warm ice surface into the atmospheric boundary layer, with recent research suggesting a dominating role of the latter (Style and Worster, 2009). In both cases, however, their fine structure provides a means of wicking surface brine toward the colder lower atmosphere (Roscoe et al., 2011). Evaporation to the atmosphere further concentrates the brines expelled to the ice surface, and ikaite forms rapidly. Formation of ikaite will result in $\mathrm{CO}_{2}$ production according to the reaction

$\mathrm{Ca}^{2+}+2 \mathrm{HCO}_{3}^{-}+5 \mathrm{H}_{2} \mathrm{O} \leftrightarrow \mathrm{CaCO}_{3} 6 \mathrm{H}_{2} \mathrm{O}+\mathrm{CO}_{2}$.

Most of the $\mathrm{CO}_{2}$ that is formed in this way near the ice surface is likely released to the atmosphere, resulting in highly alkaline surface pH (bulk values; Hare et al., 2013). Thus, our data add credibility to the recent suggestions that sea ice can act as a source of $\mathrm{CO}_{2}$ to the atmosphere during cold conditions and new ice formation (Nomura et al., 2006; Rysgaard et al., 2011; Geilfus et al., 2013a). At present, we lack data to evaluate the relative importance of ikaite formation, in addition to changes in $\mathrm{TCO}_{2}$ concentration, equilibrium constants, and $\mathrm{CO}_{2}$ solubility, for controlling $\mathrm{CO}_{2}$ flux to the atmosphere. However, the ikaite being produced on the sea ice surface will, according to Eq. (1), take up an equal part of $\mathrm{CO}_{2}$ when sea ice melts and mixes with ocean surface water and the ikaite crystals are dissolved. Hence, provided the ikaite dissolves, the thin surface layer of sea ice should not have a net effect on the annual air-sea $\mathrm{CO}_{2}$ flux, but instead represent a closed $\mathrm{CO}_{2}$ loop where release and uptake are separated in time. If the sea ice surface is covered by snow shortly after frost flower formation, $\mathrm{CO}_{2}$ may accumulate in the snowpack. Strong winds may then ventilate the snowpack and release this $\mathrm{CO}_{2}$ to the atmosphere, which may explain some of the findings in the literature reporting 


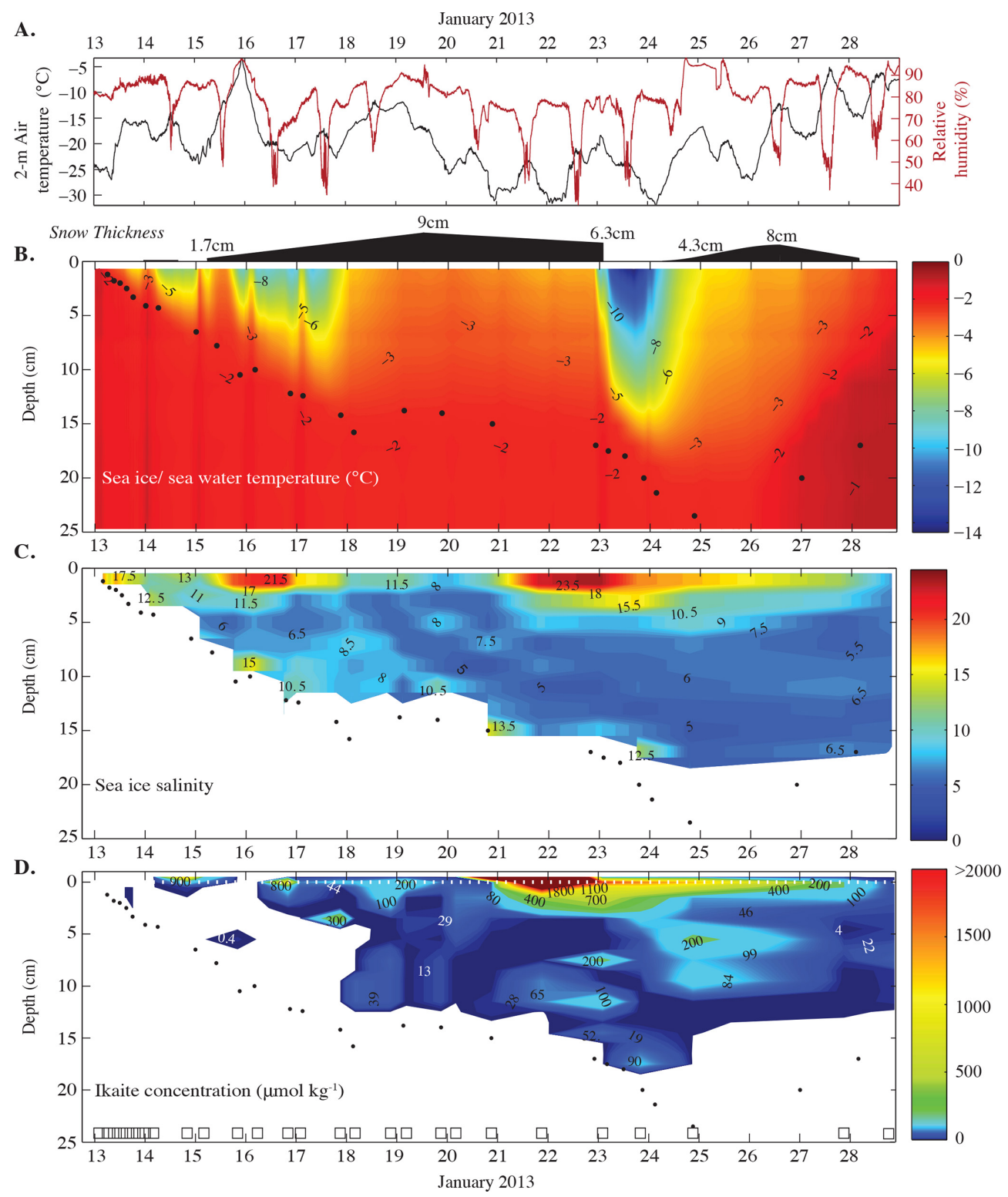

Figure 2. (A) Air temperature (black lines) and relative humidity (red lines), (B) snow cover (black horizontal bars) and sea ice/water temperature $\left({ }^{\circ} \mathrm{C}\right),(\mathbf{C})$ bulk ice salinity (psu), and (D) Bulk ikaite concentration $\left(\mu \mathrm{mol} \mathrm{kg}{ }^{-1}\right.$ sea ice) in experimental sea ice grown at the Sea-ice Environmental Research Facility (SERF) during 13-30 January 2013. In (D), the horizontal dotted line in upper sea ice layers (above 0) represents the BS and FF layer. In panels (B) to (D), sea ice thickness is illustrated by black dots. Open squares in the lower part of (D) mark the sampling times of ikaite.

high short-lived $\mathrm{CO}_{2}$ fluxes during winter by eddy covariance (e.g., Papakyriakou and Miller, 2011a; Miller et al., 2011b; Else et al., 2011).

Even though ikaite concentrations in FFs (note FF density is low, $0.02 \mathrm{~g} \mathrm{~cm}^{-3}$; Domine et al., 2005) and the $1-2 \mathrm{~mm}$ thick BS are high, their importance to the total ikaite concentration in sea ice will decrease with increased sea ice thickness. They are also relatively short-lived, occurring only over new and young sea ice under specific environmental conditions (e.g., Style and Worster, 2009). At maximum FF and
BS concentrations (21-23 January), FFs and BS would have accounted for $7-15 \%$ of the total ikaite had they covered the entire SERF pond, whereas on 25 January they would have only accounted for $2-4 \%$. This is in general agreement with findings from field studies where FFs and BS in newly formed $(20 \mathrm{~cm}$ thick) sea ice fully covered by FFs accounted for only $5 \%$ of the total ikaite (Barber et al., 2014).

We employed the FREZCHEM model to calculate theoretical equilibrium ikaite concentrations as a function of different sea ice temperatures in SERF seawater with different 


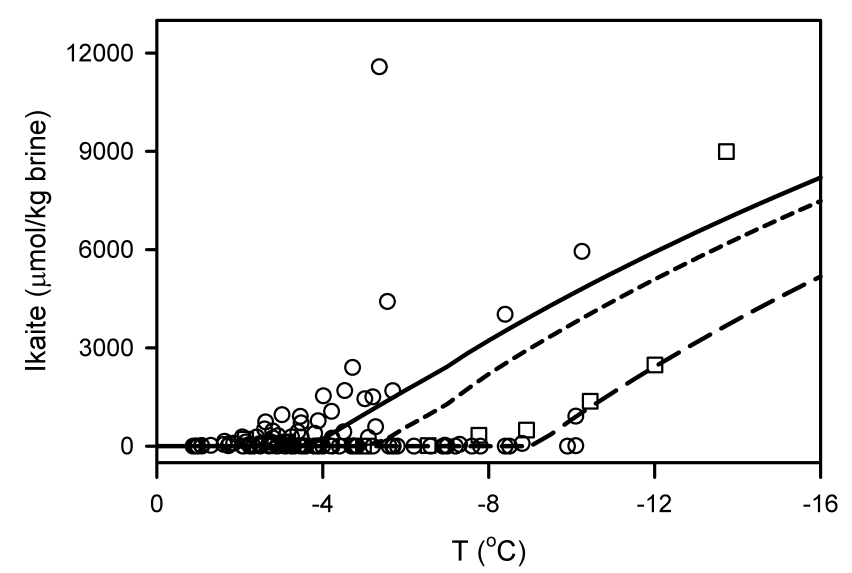

Figure 3. Abundance of ikaite in sea ice, expressed as ikaite concentration in brine, as a function of temperature. Symbols are observed ikaite concentrations at SERF from this work (circles: measurement within 30 min of sample collection; squares: samples taken on January 24 after the snow clearance). The lines show equilibrium ikaite concentrations modeled by FREZCHEM as $1 \mathrm{~kg}$ of SERF seawater $(S=32.9$, TA $=2380 \mu \mathrm{mol} \mathrm{kg}-1)$ freezes from 0 to $-16^{\circ} \mathrm{C}$ under different $p \mathrm{CO}_{2}$ values: $390 \mu \mathrm{atm}$ (solid line), $1000 \mu \mathrm{atm}$ (short dashed line), and $5000 \mu$ atm (long dashed line).

$p \mathrm{CO}_{2}$ values (Fig. 3). Ikaite concentrations are reported as per mass of brine, since this should be the dominating control on ikaite abundance at a given temperature. The high FF and BS concentrations are not included in Fig. 3 because of their large density variations, which make comparisons by weight difficult. As can be seen from Fig. 3, the temperature onset for ikaite precipitation with SERF seawater at $390 \mu$ atm $p \mathrm{CO}_{2}$ is $-4{ }^{\circ} \mathrm{C}$ and ikaite concentration increases to $\sim 8000 \mu \mathrm{mol} \mathrm{kg}{ }^{-1}$ brine at $-16^{\circ} \mathrm{C}$. When the $p \mathrm{CO}_{2}$ increases to $1000 \mu \mathrm{atm}$, ikaite will not start to form until $-5.5^{\circ} \mathrm{C}$, and its concentration increases to $\sim 7500 \mu \mathrm{mol} \mathrm{kg}^{-1}$ brine at $-16^{\circ} \mathrm{C}$. At a $p \mathrm{CO}_{2}$ of $5000 \mu \mathrm{atm}$, the temperature threshold for ikaite formation decreases to $-9{ }^{\circ} \mathrm{C}$, and the ikaite concentration reaches only about $\sim 5000 \mu \mathrm{mol} \mathrm{kg}^{-1}$ brine at $-16^{\circ} \mathrm{C}$. We did not measure $p \mathrm{CO}_{2}$ in the SERF sea ice brine during this study; however, field studies have shown that during sea ice growth brine $p \mathrm{CO}_{2}$ varies greatly from near the atmospheric $p \mathrm{CO}_{2}$ value $(\sim 390 \mu \mathrm{atm})$ to more than an order of magnitude higher (e.g., Miller et al., 2011a, b). Therefore, the $p \mathrm{CO}_{2}$ range (390-5000 $\mu$ atm) used in our FREZCHEM modeling should bear some relevance to the $p \mathrm{CO}_{2}$ environment in SERF sea ice brine. As shown in Fig. 3, the observed temperature onset of ikaite formation and the measured ikaite concentrations in SERF sea ice are generally supported by the FREZCHEM model within the prescribed $p \mathrm{CO}_{2}$ range.

The observed ikaite concentrations in the SERF sea ice (Fig. 2d) and the modeled concentrations from FREZCHEM (Fig. 3) suggest that ikaite concentration in the brine in general increases with decreasing temperatures. The precipita- tion of ikaite will only occur when the ion activity product (IAP) of $\left\{\mathrm{Ca}^{2+}\right\}\left\{\mathrm{CO}_{3}^{2-}\right\}\left\{\mathrm{H}_{2} \mathrm{O}\right\}^{6}$ exceeds the solubility product $\left(K_{\mathrm{sp}}\right)$ of ikaite. When $p \mathrm{CO}_{2}$, TA, and total $\mathrm{Ca}^{2+}$ concentrations are held constant, temperature is the primary control of the activities of $\mathrm{Ca}^{2+}$ and $\mathrm{CO}_{3}^{2-}$ due to its control over brine salinity. This is congruent with the understanding that cold sea ice temperatures cause reduced brine volume (e.g., Assur, 1960; Bennington, 1967; Lake and Lewis, 1970; Cox and Weeks, 1983; Perovich and Gow, 1996; Cole and Shapiro, 1998; Eicken et al., 2000) and increased brine salinity, which in turn increases concentration of $\mathrm{Ca}^{2+}$ and $\mathrm{HCO}_{3}^{-}$sufficiently to allow for ikaite precipitation. When $p \mathrm{CO}_{2}$ changes, however, both the temperature threshold for ikaite formation and the equilibrium ikaite concentration will change. This is understandable as, when $\mathrm{Ca}^{2+}$ and TA are held constant (as is the case shown in Fig. 3), the temperature threshold will be a function of $p \mathrm{CO}_{2}$ : higher $p \mathrm{CO}_{2}$ results in a lower $\mathrm{pH}$, and as a result ikaite will not precipitate until the ice is much colder. At that temperature or lower, the corresponding IAP in the brine equals or exceeds $K_{\text {sp }}$ of ikaite at the specific temperature, and thus ikaite starts to precipitate. For instance, with the SERF seawater at $p \mathrm{CO}_{2}=390 \mu \mathrm{atm}$, at $T=-3.5^{\circ} \mathrm{C}$ the IAP is $4.55 \times 10^{-8}$, which is less than the corresponding $K_{\text {sp }}$ of $5.03 \times 10^{-8}$ (extrapolated from Bischoff et al., 1993, by Marion, 2001). Therefore, there would be no precipitation of ikaite. When the temperature is lowered to $-4{ }^{\circ} \mathrm{C}$, IAP exceeds the corresponding $K_{\mathrm{sp}}$ of $4.87 \times 10^{-8}$, and as such $214 \mu \mathrm{mol} \mathrm{kg}{ }^{-1}$ brine of ikaite needs to be formed to bring down the IAP to equal to the $K_{\mathrm{sp}}$. A further decrease in temperature results in more ikaite being precipitated out from the brine, along with the precipitation of several other minerals such as mirabilite and to a lesser extent gypsum (Geilfus et al., 2013b).

Although temperature (through its regulation of brine concentration and $p \mathrm{CO}_{2}$ ) appears to control ikaite concentrations during the SERF experiment, there are several other processes that should be considered. Low ikaite concentrations were typically found in the lower-middle part of the SERF sea ice where bulk salinities were lowest. These low values could in principle be caused by the loss of crystals to the underlying water column due to their relatively high density. The sea ice volume temperature and bulk salinity profiles (Fig. 2) indicate that for a brief period between 23 and 24 January, the volume should have been permeable to fluid transport in light of the "rule of fives" proposed by Golden et al. (1998). However, this scenario seems unlikely based on FREZCHEM modeling that predicts few crystals should form within these lower ice layers due to warmer temperatures. The low internal ikaite concentration could also be a result of ikaite dissolving due to slightly lower $\mathrm{pH}$ values (due to higher $p \mathrm{CO}_{2}$ ) caused by downward transport of $\mathrm{pH}$ equivalents originating from ikaite production in surface ice layers (see Hare et al., 2013, for further details on $\mathrm{pH}$ within sea ice). Biological impacts 
on ikaite crystal formation/dissolution are unlikely to have played a role in this experiment, as neither organic matter nor biota were purposely introduced into this experiment, and observed average levels of bulk ice microbial activity $\left(1.12 \times 10^{-6} \mathrm{~g} \mathrm{CL}^{-1} \mathrm{~d}^{-1}\right)$ and algal Chl $a\left(0.007 \mu \mathrm{g} \mathrm{L}^{-1}\right)$ were very low.

The present study supports several key concepts described in a recent conceptual model on the processes driving airsea gas exchange throughout the cycle of sea ice formation and decay (Rysgaard et al., 2011). First, the hypothesized release of $\mathrm{CO}_{2}$ to the atmosphere during initial precipitation of ikaite in surface layers of the sea ice can be supported by our observations of high ikaite concentration in BS and FFs. One should bear in mind here, however, that, although the BS and FF ikaite concentrations are high, they are only an indication of a flux to the atmosphere. The size of the flux is not necessarily large (See also Nomura et al., 2006 for additional information on this matter). In SERF, ikaite formation seems to be high above the freeboard where temperatures are low and brine concentrations high. Secondly, the SERF experiment showed that ikaite crystals start to dissolve when temperatures start to rise and sea ice starts to melt. The quick dissolution of ikaite crystals in melting sea ice during this ice tank experiment supports previous observations that sea ice melt water is severely $\mathrm{CO}_{2}$ undersaturated relative to the atmosphere (Rysgaard et al., 2012; Else et al., 2013; Geilfus et al., 2012).

The SERF study also suggests that the process of ikaite precipitation and dissolution may occur multiple times between fall freeze-up and summer melt as a function of snow, temperature, and $p \mathrm{CO}_{2}$ conditions. Thus, dynamic conditions of ikaite crystals, $\mathrm{CO}_{2}$, and $\mathrm{pH}$ are expected even during winter. This could have several implications for the exchange of carbonate species between sea ice and the underlying water. One possibility is that $\mathrm{CO}_{2}$ released from ikaite precipitation in sea ice during cold periods is rejected to the underlying water. A new snowfall or a redistribution of snow due to high winds to the same site may warm the sea ice cover locally. This will increase brine volumes, sea ice permeability, and the contact of the brine system with the underlying water, which depending on the $p \mathrm{CO}_{2}$ conditions in the water column may dissolve ikaite. Dissolution of ikaite will increase TA and pH conditions in the near-ice-surface "melt water". The overall outcome is that sea ice may be responsible for low- $p \mathrm{CO}_{2}$ conditions in the ice-covered surface waters even in wintertime (e.g., Else et al., 2012). This mechanism of separating low- $p \mathrm{CO}_{2}$ surface waters from deeper high- $p \mathrm{CO}_{2}$ waters is supported by recent observations from a polynya site in NE Greenland where very low $p \mathrm{CO}_{2}$ concentrations were observed near the sea ice-water interface (Rysgaard et al., 2013). Another possibility is that ikaite forms on the surface sea ice layers via flooding and that $\mathrm{CO}_{2}$ released from ikaite precipitation will be released to the atmosphere. Thus, melting of sea ice will not have a net effect on the $\mathrm{CO}_{2}$ flux between air and seawater but rather take up the same amount of released $\mathrm{CO}_{2}$ from the atmosphere. As a final remark, it should be mentioned that, in any given sea ice area, several different sea ice stages of development (thicknesses) may be present at one particular time as a result of broadscale sea ice dynamical processes. This means that the process of ikaite development can be at different stages in its evolution within a relatively small region.

\section{Conclusions}

In our study, ikaite precipitated in sea ice at temperatures below $-4{ }^{\circ} \mathrm{C}$, creating three distinct zones of ikaite concentrations: (1) a millimeter-to-centimeter-thin surface layer containing frost flowers and brine skim with bulk concentrations of $>2000 \mu \mathrm{mol} \mathrm{kg}{ }^{-1}$, (2) an internal layer with localized concentrations of $200-400 \mu \mathrm{mol} \mathrm{kg}{ }^{-1}$, and (3) a bottom layer with concentrations of $<100 \mu \mathrm{mol} \mathrm{kg}{ }^{-1}$. Snowfall events cause sea ice to warm, leading to the dissolution of ikaite crystals under snow conditions. Removal of the snow cover allows the sea ice to cool and brine salinities to increase, resulting in rapid ikaite precipitation. Thus, varying snow conditions may play a key role in ikaite precipitation and dissolution at the surface of sea ice. This will have implications for $\mathrm{CO}_{2}$ exchange with the atmosphere. The modeled ikaite concentrations from FREZCHEM are on the same order of magnitude as observations and suggest that ikaite concentration in sea ice increases with decreasing temperatures. However, more developments on the FREZCHEM model and better understanding of the kinetics of ikaite precipitation and dissolution are needed to allow more reliable predictions of ikaite concentrations. In particular, our results call for the coupling of FREZCHEM to a model that can interactively simulate the loss of salts to the underlying water during ice formation.

Acknowledgements. This study was funded by the Canada Excellence Research Chair (CERC, S. Rysgaard) and the Natural Sciences and Engineering Research Council (NSERC) of Canada (F. Wang, T. Papakyriakou). SERF was funded by the Canada Foundation of Innovation (CFI), the Manitoba Research and Innovation Fund, and the University of Manitoba. We would like to thank G. Marion for his assistance with version 13.3 of FREZCHEM and Rebecca Rolph for her help in plotting Fig. 2. This work is a contribution to the Arctic Science Partnership (ASP) and the ArcticNet Networks of Centres of Excellence programs.

Edited by: J.-L. Tison

\section{References}

Assur, A.: Composition of sea ice and its tensile strength, U.S. Army snow ice and permafrost research establishment, research report 44, corps of engineers, Wilmette, Illinois, December 1960.

Barber D. G., Ehn, J. K., Pucko, M., Rysgaard, S., Papakyriakou, T., Deming, J., Galley, R., and Søgaard, D.: Frost flowers on young 
Arctic sea ice: The climatic, chemical and microbial significance of an emerging ice type, J. Geophys. Res.-Atmos., revised, 2014.

Bates, N. R. and Mathis, J. T.: The Arctic Ocean marine carbon cycle: evaluation of air-sea $\mathrm{CO}_{2}$ exchanges, ocean acidification impacts and potential feedbacks, Biogeosciences, 6, 2433-2459, doi:10.5194/bg-6-2433-2009, 2009.

Bennington, K. O.: Desalination features in natural sea ice, J. Glaciol., 6, 845-857, 1967.

Bischoff, J. L., Fitzpatrick, J. A., and Rosenbauer, R. J.: The solubility and stabilization of ikaite $\left(\mathrm{CaCO}_{3} \cdot 6 \mathrm{H}_{2} \mathrm{O}\right)$ from $0^{\circ}$ to $25^{\circ} \mathrm{C}$ : Environmental and paleoclimatic implications for thinolite tufa, J. Geol., 101, 21-33, 1993.

Cavalieri, D. J. and Parkinson, C. L.: Arctic sea ice variability and trends, 1979-2010, The Cryosphere, 6, 881-889, doi:10.5194/tc6-881-2012, 2012.

Cole, D. M. and Shapiro, L. H.: Observations of brine drainage networks and microstructure of first-year sea ice, J. Geophys. Res., 103, 21739-21750, 1998.

Cox, G. F. N. and Weeks, W. F.: Equations for determining the gas and brine volumes in sea ice samples, J. Glaciol., 29, 306-316, 1983.

Dieckmann, G. S., Nehrke, G., Papadimitriou, S., Göttlicher, J., Steininger, R., Kennedy, H., Wolf-Gladrow, D., and Thomas, S. N.: Calcium carbonate as ikaite crystals in Antarctic sea ice, Geophys. Res. Lett., 35, L08501, doi:10.1029/2008GL033540, 2008.

Dieckmann, G. S., Nehrke, G., Uhlig, C., Göttlicher, J., Gerland, S., Granskog, M. A., and Thomas, D. N.: Brief Communication: Ikaite $\left(\mathrm{CaCO}_{3} \cdot 6 \mathrm{H}_{2} \mathrm{O}\right)$ discovered in Arctic sea ice, The Cryosphere, 4, 227-230, doi:10.5194/tc-4-227-2010, 2010.

Domine, F., Taillandier, A. S., Simpson, W. R., and Severin, K.: Specific surface area, density and microstructure of frost flowers, Geophys. Res. Lett., 32, L13502, doi:10.1029/2005GL023245, 2005.

Eicken, H., Bock, C., Wittig, R., Miller, H., and Poertner, H.-O.: Magnetic resonance imaging of sea-ice pore fluids: methods and thermal evolution of pore microstructure, Cold Reg. Sci. Technol., 31, 207-225, 2000.

Else, B. G. T., Papakyriakou, T. N., Galley, R. J., Drennan, W. M., Miller, L. A., and Thomas, H.: Wintertime $\mathrm{CO}_{2}$ fluxes in an arctic polynya using eddy covariance: Evidence for enhanced air-sea gas transfer during ice formation, J. Geophys. Res., 116, C00G03 doi:10.1029/2010JC006760, 2011.

Else, B. G. T., Papakyriakou, T. N., Galley, R. J., Mucci, A., Gosselin, M., Miller, L. A., Shadwick, E. H., and Thomas, $\mathrm{H}$ : : Annual cycles of $p \mathrm{CO}_{2 \mathrm{sw}}$ in the southeastern Beaufort Sea: New understandings of air-sea $\mathrm{CO}_{2}$ exchange in arctic polynya regions, J. Geophys. Res.-Oceans, 117, C00G13, doi:10.1029/2011JC007346, 2012

Else, B. G. T., Galley, R. J., Lansard, B., Mucci, A., Papakyriakou, T. N., Brown, K., Tremblay, J.-É., Babb, D., Barber, D., Miller, L. A., and Rysgaard, S.: Further observations of a decreasing atmospheric $\mathrm{CO}_{2}$ uptake capacity in the Canada Basin (Arctic Ocean) due to sea ice loss, Geophys. Res. Lett., 40, 1132-1137, doi:10.1002/grl.50268, 2013.

Geilfus, N.-X., Carnat, G., Papakyriakou, T., Tison, J.-L., Else, B., Thomas, H., Shadwick, E., and Delille, B.: Dynamics of $p \mathrm{CO}_{2}$ and related air-ice $\mathrm{CO}_{2}$ fluxes in the Arctic coastal zone (Amundsen Gulf, Beaufort Sea), J. Geophys. Res.-Oceans, 117, C00G10, doi:10.1029/2011JC007118, 2012.
Geilfus, N.-X., Carnat, G., Dieckmann, G. S., Halden, N., Nehrke, G., Papakyriakou, T., Tison, J.-L., and Delille, B.: First estimates of the contribution of $\mathrm{CaCO}_{3}$ precipitation to the release of $\mathrm{CO}_{2}$ to the atmosphere during young sea ice growth, J. Geophys. Res.Oceans, 118, 244-255, doi:10.1029/2012JC007980, 2013a.

Geilfus, N.-X., Galley, R., Hare, A., Wang, F., Søgaard, D., and Rysgaard, S.: Ikaite and gypsum crystals observed in experimental and natural sea ice, Geophys. Res. Lett.. 40, 6362-6367, doi:10.1002/2013GL058479, 2013b.

Golden, K. M., Ackley, S. F., and Lytle, V. I.: The percolation phase transition in sea ice, Science, 282, 2238 , doi:10.1126/science.282.5397.2238, 1998.

Grasshoff, K., Erhardt, M., and Krembling, K.: Methods of seawater analysis, 2nd revised and extended version, Verlag Chemie, Weinheim, Deefield Beach, Fla., 1983.

Hare, A., Wang, F., Barber, D., Gelfus, N.-X., Galley, R. J., and Rysgaard, S.: $\mathrm{pH}$ evolution in sea ice grown at an outdoor experimental facility, Mar. Chem., 154, 46-54, doi:10.1016/j.marchem.2013.04.007, 2013.

Hesse, K. F. and Küppers, H.: Refinement of the structure of Ikaite, $\mathrm{CaCO}_{3} \cdot 6 \mathrm{H}_{2} \mathrm{O}$, Zeitschrift für Kristallographie, 163, 227-231, 1983.

Lake, R. A. and Lewis, E. L.: Salt rejection by sea ice during growth, J. Geophys. Res., 75, 583-597, 1970.

Marion, G. M.: Carbonate mineral solubility at low temperatures in the Na-K-Mg-Ca-H-Cl-SO $-\mathrm{OH}-\mathrm{HCO}_{3}-\mathrm{CO}_{3}-\mathrm{CO}_{2}-\mathrm{H}_{2} \mathrm{O}$ system, Geochim. Cosmochim. Ac., 65, 1883-1896, 2001.

Marion, G. M. and Kargel, J. S.: Cold Aqueous Planetary Geochemistry with FREZCHEM: From Modeling to the Search for Life at the Limits, Springer, Heideberg, 251 pp., 2008.

Marion, G. M., Farren, R. E., and Komrowski, A. J.: Alternative pathways for seawater freezing, Cold Reg, Sci. Technol., 29, 259-266, 1999.

Marion, G. M., Mironenko, M. V., and Roberts, M. W.: FREZCHEM: a geochemical model for cold aqueous solutions, Comput. Geosci., 36, 10-15, 2010.

Miller, L. A., Carnat, G., Else, B. G. T., Sutherland, N., and Papakyriakou, T.: Carbonate system evolution at the Arctic Ocean surface during autumn freeze-up, J. Geophys. Res., 116, C00G04, doi:10.1029/2011JC007143, 2011a.

Miller, L. A., Papakyriakou, T., Collins, R. E., Deming, J. W., Ehn, J. K., Macdonald, R. W., Mucci, A., Owens, O., Raudsepp, M., and Sutherland, N.: Carbon dynamics in sea ice: A winter flux time series, J. Geophys. Res.-Oceans, 116, C02028, doi:10.1029/2009JC006058, 2011b.

Millero, F. J.: Chemical Oceanography 4th edition, CRC Press 30, Taylor \& Francis Group, Boca Raton, Florida, USA, 547 pp., 2006.

Nomura, D., Yoshikawa-Inoue, H., and Toyota, T.: The effect of sea-ice growth on air-sea $\mathrm{CO}_{2}$ flux in a tank experiment. Tellus, 58, 418-426, 2006.

Papakyriakou, T. and Miller, L.: Springtime $\mathrm{CO}_{2}$ exchange over seasonal sea ice in the Canadian Arctic Archipelago, Ann. Glaciol., 52, 215-224, 2011.

Parmentier, F. J. W., Christensen, T. R., Sørensen, L. L., Rysgaard, S., McGuire, A. D., Miller, P. A., and Walker, D. A.: The impact of a lower sea-ice extent on Arctic greenhouse-gas exchange, Nature Climate Change, 3, 195-202, doi:10.1038/nclimate1784, 2013. 
Perovich, D. K. and Gow, A. J.: A quantitative description of sea ice inclusions, J. Geophys. Res., 101, 18327-18343, 1996.

Roscoe, H. K., Brooks, B., Jackson, A. V., Smith, M. H., Walker, S. J., Obbard, R. W., and Wolff, E. W.: Frost flowers in the laboratory: Growth, characteristics, aerosol and the underlying sea ice, J. Geophys. Res., 116, D12301, doi:10.1029/2010JD015144, 2011.

Rysgaard, S., Bendtsen, J., Delille, B., Dieckmann, G., Glud, R. N., Kennedy, H., Mortensen, J., Papadimitriou, S., Thomas, D., and Tison, J.-L.: Sea ice contribution to air-sea $\mathrm{CO}_{2}$ exchange in the Arctic and Southern Oceans, Tellus B, 63, 823-830, doi:10.1111/j.1600-0889.2011.00571.x, 2011.

Rysgaard, S., Glud, R. N., Lennert, K., Cooper, M., Halden, N., Leakey, R. J. G., Hawthorne, F. C., and Barber, D.: Ikaite crystals in melting sea ice - implications for $p \mathrm{CO}_{2}$ and $\mathrm{pH}$ levels in Arctic surface waters, The Cryosphere, 6, 901-908, doi:10.5194/tc6-901-2012, 2012.
Rysgaard, S., Søgaard, D. H., Cooper, M., Pućko, M., Lennert, K., Papakyriakou, T. N., Wang, F., Geilfus, N. X., Glud, R. N., Ehn, J., McGinnis, D. F., Attard, K., Sievers, J., Deming, J. W., and Barber, D.: Ikaite crystal distribution in winter sea ice and implications for $\mathrm{CO}_{2}$ system dynamics, The Cryosphere, 7, 707-718, doi:10.5194/tc-7-707-2013, 2013.

Style, R. W. and Worster, M. G.: Frost flower formation on sea ice and lake ice, Geophys. Res. Lett., 36, L11501, doi:10.1029/2009GL037304, 2009. 